\title{
THE WORK CONTENTS OF THE PERSONNEL SPECIALIST IN LATVIA
}

\author{
Reinis Lazda, ${ }^{1}$ Armands Kalnins ${ }^{2}$ \\ IAlberta College,Latvia, reinis.lazda@gmail.com \\ ${ }_{2}^{2}$ Alberta College, Latvia, armands5578@inbox.lv
}

\begin{abstract}
The contents in the work of personnel specialist differ in organizations from one field to another. It continues to evolve with an emergence of new technologies and business methods, as well as with structural changes in the economy, both at a global and national level. However, the existing professional regulations of particular professions in Latvia has not been changed for almost 10 years, while the economy as well as the workforce appears to have changed. The aim of the paper is to illustrate what currently forms the contents of work of personnel specialist in Latvia. To achieve this, a study on trends in the work of personnel specialists has been conducted with an informative support of Latvian Association for People Management. The topics of daily activities and tasks, as well as individual features of personnel in various fields, including building, banking, manufacturing, IT, retail company, and public service companies have been included in the study. Overall, 18 personnel specialists from public and private sectors were interviewed. The results show that the classical model of human resource management is still popular, although some of the industries have adapted many or most of the cutting-edge approaches in the field, including flexible jobs and continuous employee support. Therefore, it is advised to update the existing documentation, including the professional regulation and university curricula, to meet the needs of the contemporary companies employing personnel specialists.
\end{abstract}

Keywords: personnel specialist; contents of work

JEL Classification: J80

\section{Introduction}

The approaches to organizational management are constantly improving and becoming more effective. As to other professions, this also applies to the job of personnel specialist. However, organizational development is not a homogenous process, the new trends may be explicitly visible in some, but go virtually unnoticed in other organizations. The global tendencies are most evident in the industries with the fastest development rates and growth opportunities. At the same time, a considerable proportion of organizations has slower development rates, reacting to the latest human resource management tendencies with a delay or only in selected areas. This is especially true for territories with high unemployment rates, as well as small or loosely integrated organizations, with low levels of labour division, sometimes integrating human resource management within a broader scope of organizational management.

Although there is a functioning professional standard for personnel specialists in Latvia, it might have become outdated, as it has been developed within the previous economic cycle before the economic crisis of 2009 (Personāla speciālista profesijas standarts, 2009). This can have a number of consequences, starting from slower recognition of new approaches within the profession, and up to universities not updating their programs as fast as would be necessary. Without a recent research, it is also unclear to what extent the current global trends in personnel specialist profession are applicable to the organizations in Latvia.

This leads to a research question - what is the current contents of work of personnel specialists in the organizations in Latvia?

The research was based on interviews of personnel specialists in the spectrum of organizations of various fields of industry. Overall, 18 personnel specialists from 8 various organizations were interviewed. 
The results show that the classical model of human resource management is still popular, although some of the industries have adapted many or most of the cutting-edge approaches in the field, including flexible jobs and continuous employee support. When teaching the profession of personnel specialists, it is advised to supplement the existing programs with the newest approaches, as well as borderline human resource tasks, including organization of events and public communication.

\section{Literature Review}

Since the beginning of the period of industrialization, constant change, adaptation to new reality of business and integration of new business management findings has been a part of organizational management. The process is still ongoing. One of the most important carriers of organizational change has undoubtedly been the function of human resource management.

In the classical sense, the typical functions of human resource management are well known and studied (Armstrong, 2009; Kalniňs \& Čerpinska, 2014), however, the classification principles differ among the authors. In some, they are relatively detailed (Armstrong, 2009; Beardwell, Holden, \& Claydon, 2004), while others offer various higher-order classifications (Daley, 2012; Ešenvalde, 2008; Vorončuka, 2009). However, the generally more widespread processes named by all the authors are recruitment and selection, motivation, training and evaluation. A growing attention is being paid to other issues of human resource management: career management (succession planning), stress management, employee consultations and so on (Kaifeng, Lepak, Hu, \& Baer, 2012; Kalninšs \& Čerpinska, 2014).

One of the most recent issues of human resource management at the second decade of the 21 st century is introduction of new technologies and the related restructuring of organizational processes. It includes both use of information technologies for storing and more efficient use of personnel data, and organization of the required preparatory work for implementing new tools of organizational automatization (Stone \& Deadrick, 2015).

Another issue of no lesser importance is talent management or systematic approach to recruitment and selection processes, training and career management, to ensure effective meeting of the organizational objectives (Tomčíková, 2016; Dzene, 2012). Although talent management is a broad concept, currently, its most highlighted aspects are provision of the needs of a multicultural staff, integration of different generations into the labour market and attraction of talents from discriminated social groups (e.g., persons with disabilities).

However, organizational development on par with the development of human resource functions is not a homogenous process. The previously highlighted are the global tendencies that are most evident in the industries with the fastest development rates and growth opportunities. At the same time, a considerable proportion of organizations has slower development rates, reacting to the latest human resource management tendencies with a delay or only in selected areas. This is especially true for territories with high unemployment rates, as well as small or loosely integrated organizations (e.g., retail chains with scattered networks of shops), with low levels of labour division, sometimes integrating human resource management within a broader scope of organizational management.

The industry of the organization and type of activity are also of high importance, affecting both the issues of human resource management and the specifics of daily activities of personnel specialists (Datta, Guthrie, \& Wright, 2005). Depending on whether the organization is focused on attracting highly skilled professionals or less qualified employees or recruiting specialists in professions with the lack specialists in the field, the methods used by the personnel specialist during the process of recruitment and selection differ significantly. The organizations are also classified by the main focus of human resource management systems - commitment-based or productivity-based organizations (Lepak \& Snell, 2002).

The qualifications required for a personnel specialist can be obtained at higher education institutions. In Latvia, the required qualifications are defined in a professional standard approved by the Cabinet of Ministers (MK Noteikumi Nr. 461, 2010). However, the concept of any profession is inevitably rooted in the situation of the past. It should also be noted that the tasks set out by the professional standard 
are formulated using a profoundly general phrasing, like 'ability to manage recruitment process' or 'able to solve problems'. Although this meets the requirement of the document of being reasonably general and applicable, this also hampers from drawing clear conclusions. To ensure the knowledge and skills correspond to the tasks personnel specialist will face, the information should be obtained on both current requirements in the organizations, and also future tendencies. Also, a probability that within a globalized economy and labour market conditions, the person could move to work in another country.

The economy of Latvia as a small country is characterized by companies of relatively modest size. There are only three private companies employing more than 1000 persons, and the number of employees exceed 500 in 101 organizations (Valsts ienēmumu dienests, 2016). However, the level of unemployment has substantially decreased, thus reaching one of the lowest levels since such data are available (Fig. 1).

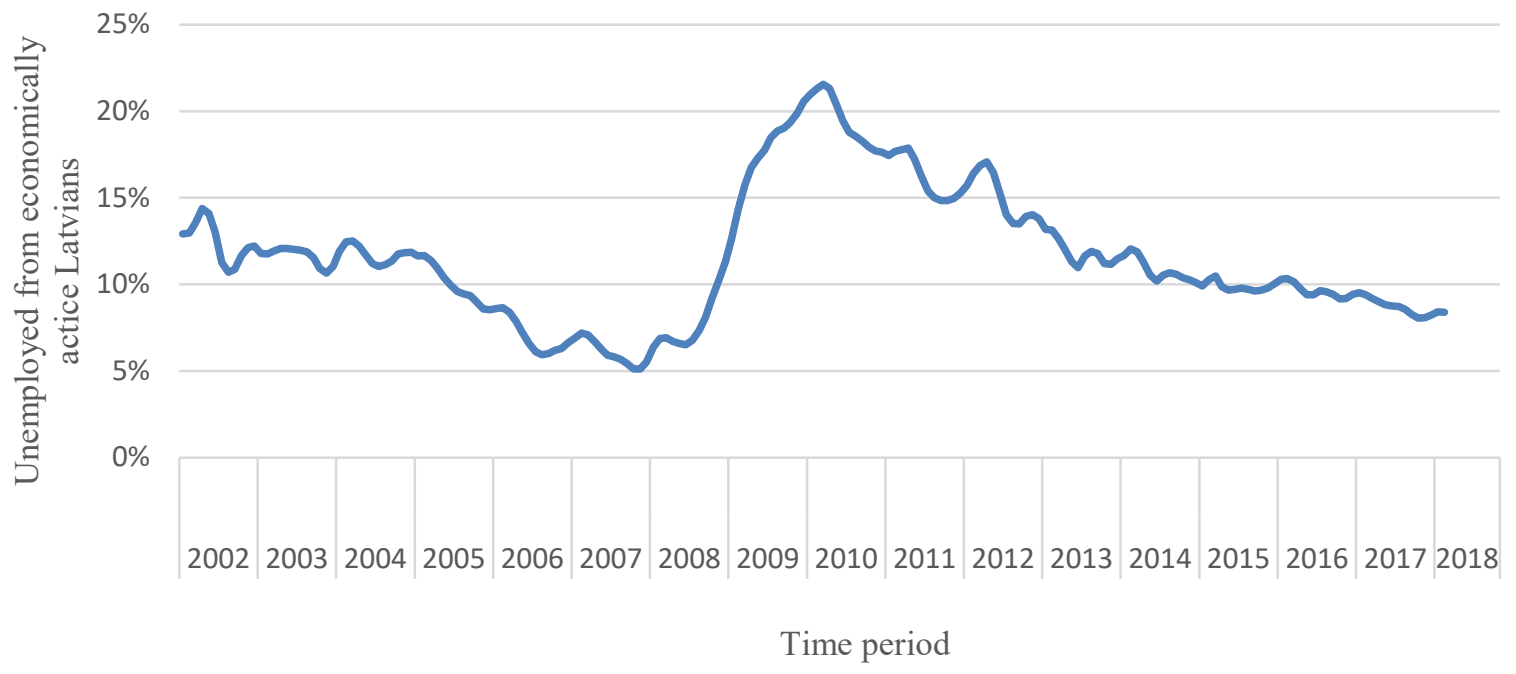

Fig. 1. Unemployment in Latvia at the age 15-74 (Source: Centrālā statistikas pārvalde, 2018)

The mean monthly salary also has a steady growth trend, reaching 676 euros net and 758 euros net in Riga, the region with the highest economic activity. Compared to the year 2012, this is a growth of 38 per cent (Centrālā statistikas pārvalde, 2018). This leads to a question - what is the current contents of work of personnel specialists in the organizations in Latvia?

The most typical approach of analysing the jobs is to analyse a number of jobs at the same organization (Morgeson \& Dierdorff, 2011). In this case, the objective is different - to assess the extent to which it is possible to summarize the tasks and requirements under the same label of personnel specialist. As mentioned by one of the interviewed representatives: 'We are not interested in the typical graduates of the higher education institutions. We have our own agenda which does not correspond to the requirements in other organizations.'

What is important when summarizing the requirements for representatives of a particular job? Certainly, the main tasks form the core of a job description. However, there are also other traditional sections included - the main objectives of work, the numerical code according to the classification of professions, the place within the larger organizational structure, necessary competencies, and requirements for education and previous experience.

To ensure accurate information on the specifics of the job, a job analysis is performed. It is one of the oldest practices of contemporary human resource management, often seen as a cornerstone for creating an overview of both the job and the organization in general (Sanchez \& Levine, 2012). Still, the paradigm of job analysis is a process of ongoing change, caused by increasingly undefined and variable borders of organizational structures and professions. As a result, the approaches to job 
analysis and person-job compatibility determination allowing flexible response to change at the workplace are of increasing popularity.

In the recent years, to stress the changes to the approach, a new and generalized term 'work analysis' is being used, including a systematic analysis of job requirements, as well as offering a wider context to situations where the job requirements are manifested (Morgeson \& Dierdorff, 2011).

Using a comparable approach, work analysis has recently been performed for accountants and managers in the local context (Kalniņš, Ķirse, \& Čivžele, 2015). Similar research on human resource specialists is no less important, as it would allow to improve the contents of the education program according to the current needs of organizations.

\section{Methodology}

The interviews were held at the premises of the organizations, with one, two, or three interviewers. In all the interviews, the first author of the article was present, the other interviewees being students involved in the research process. The process of interviewing took on average one hour, the shorter interviews being 20 minutes long, but the longest interviews took 1.5 hours. The shorter interviews were held at the organizations with several personnel specialists, so each of them answered questions only about their specific tasks.

A set of questions was developed for the interviews. With this research analysis, the first focus of research questions is on the typical tasks of the personnel specialists: what tasks make the typical days, what tasks are also important but less routine, and also what are irregular but presumed or probable. However, the interview also included other related questions: the specifics of the organizational structures (work organization, the comparative complexity of tasks), typical profiles of employees (age and education, educational and experience background and their life stories, work motivation and intelligence), typical problems with dealing with employees (levels of turnover, lack of motivation, burnout, communication issues, etc.), legal, seasonal and other specifics in the industry (organization of work hours), evaluation criteria of personnel specialists. Additional questions were asked if these appeared to lead to more insight in understanding the problem.

The participants were selected to cover as wide range of industries as possible, while maintaining the profile of large organizations (i.e., at least 200 employees), including building, banking, manufacturing, IT, retail company, and public service companies have been included in the study. Overall, 18 personnel specialists from 8 public and private sector organizations in Latvia were interviewed. From these organizations, three are local branches of international companies, two are public companies of mainly local capital, and one is privately held company of local investors. All of them are active members of Latvian Association for People Management, which invited the companies to participate in the research.

\section{Results}

\section{Role of a Personnel Specialist}

The status of Human Resource management differs between organizations. In some, the representative of the department is also a member of the board, while in some of the others, this is not the case. In many cases, the direct superior of the head of Human Resource department is the chief executive of the company, but not in all of the cases. In some organizations, the direct superiority of chief executive means representation in the board, but sometimes not.

To a certain extent, the place of Human Resource department in the organizational structures can be explained by the relatively small number of employees (for large organizations). However, this is not always the case, as the authority of Human Resource department can be limited even in the largest organizations. 
For example, the head of Human Resource department at Accenture Latvia is both a direct subordinate of the chief executive, and member of board. At Rural Support Service, the head is a direct subordinate but does not have a status of a chief officer.

The number of jobs at the human resource department is also a variable. As the interviewed organizations were all large organizations, the number is between 2 and 9 employees. However, in some of the cases the HR department also serves other organizations within the same group. At VISMA, HR department is engaged in two other companies of the same group, providing them with a limited range of HR services (mostly records management), while at Accenture, HR department also offers selected records management services to Accenture branches in other countries (namely, Nordic countries).

Most of aforementioned is already well known. It can be noted that a significant number of the leading companies has already switched to the model of direct supervision of the chief executive at the company, although this review does not provide with the statistical information. Another important fact signalling globalization, is the involvement of local HR employees in managing processes in other countries. As large international enterprises choose Latvia as the place of their back offices more and more often, the skills of adapting to international work, that is, varying work cultures and legislation, will continue to grow with time.

\section{Functions of a Personnel Specialist}

Although it is clear from the research that the job of personnel specialist involves a set of tasks from the theory, the contents of these tasks often differ between organizations. In most of the organizations, recruitment is one of the dominating tasks, especially at the entry level of HR jobs. In most organizations with several HR jobs, one or more positions are dedicated solely to recruitment.

However, the contents of recruitment differ. At the company of road construction, the main recruitment problem is recruiting unskilled seasonal workers. At the retail chain, the HR department only organizes the first phases of recruitment, while shop managers themselves interview the candidates. Then, if the process of selection is successful, HR department joins back in and prepares employment contract and other necessary documents.

At the state authority, the problem is attracting candidates to the regions with the highest salaries. At the technology companies with a limited pool of candidates, there are two solutions. One, to identify potentially talented candidates and to effectively educate them. Second, to attract candidates' attention to consider job offers.

There are also exceptions. At pharmaceutical company, the employee turnover is low, and even then, many of the positions are filled with internal resources. Here, the focus is not that much on recruitment than on training.

Personnel selection covers a wide range of methods, from an unstructured interview to psychological testing and behavioural interviews. It is worth noting though that several organizations use psychological testing as a means to evaluate the candidates.

Another core task is records management. Latvian laws regulate it rather strictly, so the dominating approach to records management is to keep all the documents in paper form and signed, including vacation applications and internal orders. However, the process is being increasingly automated, and organizations are at various stages of doing it. Several companies noted that they are at the process of testing new automatization tools.

With the rising importance of professional knowledge, the importance of onboarding activities is also on the rise. The process has various interpretations; however, all the interviewed companies provide support for new employees to a varying degree. The technology company pays special attention not only to select the employees but also to offer them basic formal training ( 2 to 4 weeks) and give another 4-6 months (and sometimes even a year) in a status of an intern with access to a large database of digital training materials to finalize their preparation to work and enter a project team. Employees are mentored by HR specialists during the period. The drug production company also organizes basic certification trainings for newcomers. 
Since the human resource specialists are the first persons to get acquainted with at the company, they often become the main representatives of the company to the employees - they are often approached in the case of sick leave or other less typical situations.

In some cases, the work with employees starts long before they apply to a job or training. Cooperation with universities is widely used, university interns are accepted and later approached as candidates. In several organizations, recruitment processes start even before that. Activities for secondary school, professional school and even middle school children are organized to inform them about possibilities and requirements of work at their companies. This includes organizing trips to the company for schoolchildren, offering educational activities and so on.

The process with one of the most varied interpretations across the organizations is employee evaluation. In some of the organizations, the evaluation process is developed and strictly regulated; while in others, it largely depends on decisions of department managers and is rather situational. As a part of higher organizational flexibility, this can be a benefit from the perspective of effective use of resources. However, this can also interfere with the need of talent management.

As one of the support functions, HR department sometimes gets trusted with tasks that are only remotely related to human resource management in its classical form. The process occurring relatively often is a task of organizing internal events, like company sports games, Christmas celebrations, birthday parties, management of occupational safety and health checks, health insurance. Sometimes these are organized in cooperation with other departments or the duties are switched from year to year.

In retail chain, which is the most publicly known company among the interviewed, the human resource department is also responsible for mitigating risks from negative flow of information within social networks (e.g., Facebook, Twitter).

\section{Conclusions}

The research confirms that most personnel specialists in Latvia are indeed engaged in accomplishing the well-established duties described in the more classical textbooks. involves a set of tasks from the theory; the contents of these tasks often differ between the organizations. However, it also appears that there are also companies that go in line with contemporary tendencies in the job worldwide. These are especially evident in the companies operating in the industry of information technology where the contents of tasks correspond to the contemporary tendencies, including the flexibility of job boundaries.

One of the most peculiar source of differences lays in the field of recruitment where the information technology companies, due to the shortage of qualified specialists, invent creative ways of attracting the necessary employees and of creating a higher level of comfort at the organization.

In the organizations from other industries, the tasks roughly correspond to the more conventional models of human resource management. However, the most notable new knowledge from the research shows the relative importance of borderline processes - the tasks that are not a part of human resource management in theory, but in certain organizations are expected from human resource management departments. This includes organizing internal company-wide activities, for example, company games or celebrations, organization of health checks and health insurance, as well as being responsible for public communication about the internal issues of the organization.

This research gives a general impression on the current activities in the profession of personnel specialist. However, one should be careful to draw statistical generalizations of it. Being a qualitative research, the focus here is to identify the possible interpretations within the profession. All the companies asked to participate in the research are well established and comparatively large (to the local standards); therefore, the results may not reflect the situation in young and aspiring organizations, as well as ones that could be classified as having low levels of publicity or remote.

The conclusions could extend to additional research comparing these findings to the tasks set out by the job descriptions, as well as comparing them to the curricula of the universities to analyse the necessity to adapt to the changes in the demands of the businesses. 


\section{Acknowledgements}

Support for this work was provided by Alberta College. Informative support was provided by Latvian Association for People Management.

\section{References}

Armstrong, M. (2009). Armstrong's Handbook of Human Resource Management Practice (11 ed.). London and Philadelphia: Kogan Page.

Beardwell, I., Holden, L., \& Claydon, T. (2004). Human Resource Management: A Contemporary Approach. Harlow: Prentice Hall.

Centrālā statistikas pārvalde. (2018). Nodarbinātība un bezdarbs. Rīga. Retrieved from http://data.csb.gov.lv

Daley, D. M. (2012). Strategic Human Resource Management. In N. M. Riccucci (Ed.), Public Personnel Management (pp. 120-134). New York: Longman.

Datta, D. K., Guthrie, J. P., \& Wright, P. M. (2005). Human Resource Management and Labor Productivity: Does Industry Matter? The Academy of Management Journal, 48(1), 135-145.

Dombrovska, L. R. (2009). Cilvēkresursu kapitāla vadība. Teorija un prakse. Rīga: Zvaigzne ABC.

Dzene, S. (2012). Pēctecības plānošanas iespējas valsts pārvaldes iestādē. (Qualification paper, Alberta College, Rīga, Latvia).

Ešenvalde, I. (2008). Personāla vadības mūsdienu metodes. Rīga: Merkūrijs LAT.

Forands, I. (2002). Personāla vadība. Rīga: Latvijas izglīitîbas fonds.

Kaifeng, J., Lepak, D. P., Hu, J., \& Baer, J. C. (2012). How does human resource management influence organizational outcomes? A meta-analytic investigation of mediating mechanisms. The Academy of Management Journal, 55(6), 1264-1294.

Kalniņš, A., \& Čerpinska, S. (2014). Contribution of qualification papers in the field of personnel management to the development of organizations. Acta Prosperitatis, 5, 39-56.

Kalniňš, A., Kirse, S., \& Čivžele, O. (2015). Employers' requirements for accountants and managers regarding professional competence and skills: a study example of the Alberta college. Economics and Culture, 12, 33-44.

Lepak, D. P., \& Snell, S. A. (2002). Examining the human resource architecture: the relationships among human capital, employment and human resource configurations. Journal of Management, 28(4), 517-543.

Morgeson, F. P., \& Dierdorff, E. C. (2011). Work Analysis: From Technique to Theory. In S. Zedeck (Ed.), APA Handbook of Industrial and Organizational Psychology (Vol. 2: Selecting and Developing Members for the Organization, pp. 3-41). Washington: American Psychological Association.

Noteikumi Nr. 461 par Profesiju klasifikatoru, profesijai atbilstošiem pamatuzdevumiem un kvalifikācijas pamatprasībām un Profeiju klasifikatora lietošanas un aktualizēšanas kārtību. (2010). Latvijas Vēstnesis, 84.

Personāla speciālista profesijas standarts. (2009). Rīga: Profesionālās izglīīibas un nodarbinātības trīspusējās sadarbības apakšpadome.

Sanchez, J. I., \& Levine, E. L. (2012). The Rise and Fall of Job Analysis and the Future of Work Analysis. Annual Review of Psychology, 63, 397-425. doi:10.1146/annurev-psych-120710-100401

Stone, D. L., \& Deadrick, D. L. (2015). Challenges and opportunities affecting the future of human resource management. Human Resource Management Review, 25, 139-145.

Tomčíková, L. (2016). The most important human capital trends in stage of globalization in current time. Economy \& Society \& Environment.

Valsts ieṇēmumu dienests. (2016). Nodokḷu maksātāju (komersantu) taksācijas gadā samaksāto VID administrēto nodokḷu kopsummas. Rīga. Retrieved from https://www6.vid.gov.lv/SNK

Vorončuka, I. (2009). Personāla vadība. Rīga: Latvijas Universitāte. 